\title{
THE OWNERSHIP STRUCTURE, BOARD OF DIRECTORS, DIVERSIFICATION, AND DISCLOSURE OF ANTI-CORRUPTION POLICIES
}

\author{
Octavianus Digdo Hartomo ${ }^{1 *}$ \\ Soegijapranata Catholic University \\ IV/1, Pawiyatan Luhur St., Semarang, \\ Indonesia 50234 \\ digdo@unika.ac.id
}

\author{
Santanando Hermanto Pranatio Hutomo² \\ Soegijapranata Catholic University \\ IV/1, Pawiyatan Luhur St., Semarang, \\ Indonesia 50234 \\ digdo@unika.ac.id
}

\begin{abstract}
Anti-corruption disclosures reflect the company's commitment to prevent and combat corruption. This study examines the impact of managerial ownership, block holder ownership, government ownership, diversification, board independence, the board of commissioners' size, and diversification on anti-corruption disclosures. The object of this research is IDX listed companies from 2013 to 2017. Data obtained from the company's annual report Data analysis is multiple linear regression. The results showed that the managerial ownership, government ownership, board independence, and board size positively affected anti-corruption disclosures, block holders ownership had a negative effect, and diversification positively affected anti-corruption disclosures.
\end{abstract}

Keywords: Anti-Corruption disclosure; Ownership structure; Board of commissioners; Diversification

\begin{abstract}
ABSTRAK
Pengungkapan anti-korupsi menunjukkan komitmen perusahaan untuk mencegah dan memberantas korupsi. Penelitian ini menguji dampak kepemilikan manajerial, kepemilikan pemegang blok, kepemilikan pemerintah, diversifikasi, independensi dewan komisaris, dan ukuran dewan komisaris terhadap pengungkapan anti korupsi. Objek penelitian ini adalah perusahaan yang terdaftar di Bursa Efek Indonesia tahun 2013 -2017. Data diperoleh dari laporan tahunan perusahaan Analisis data yang digunakan adalah regresi linier berganda. Hasil penelitian menunjukkan bahwa struktur kepemilikan manajerial, struktur kepemilikan pemerintah, independensi dewan komisaris dan ukuran dewan komisaris berpengaruh positif terhadap pengungkapan anti korupsi, sedangkan struktur kepemilikan blockholder berpengaruh negatif dan diversifikasi berpengaruh positif pada pengungkapan anti korupsi.
\end{abstract}

Kata Kunci: Pengungkapan anti korupsi; Struktur kepemilikan; JEL Classification: G320

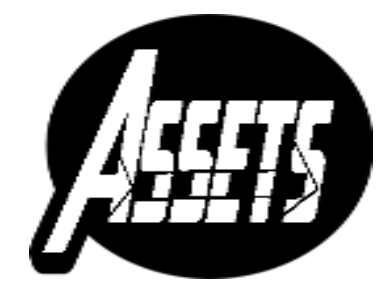

ASSETS

Jurnal Akuntansi dan Pendidikan

Vol. 9 No. 2

Page 121-130

Madiun, October 2020 p-ISSN: 2302-6251 e-ISSN: 2477-4995

Article History Submitted: December 20, 2019 Accepted: September 7, 2020 


\section{INTRODUCTION}

The anti-corruption disclosure refers to the company efforts in corruption prevention, and it signifies a company's responsibility to address this form of dishonesty in business practices. The Circular Letter of the Indonesian Financial Services Authority no. 32/SEOJK.04/2015 recommends that every company should possess anti-corruption and anti-fraud policies. However, this recommendation is halfheartedly implemented, and it is proved by the poor performance of anti-corruption disclosures of Indonesian companies (Joseph et al., 2016) and (Sari, Cahaya, \& Joseph, 2020). Anti-corruption disclosures aim to ensure company managers' accountability to the public (De Melo \& Patten, 2015). An important aspect, anti-corruption disclosure demonstrates a company's commitment to preventing, monitoring, and eradicating corruption (Healy \& Serafeim, 2016).

Using companies participating in Malaysia and Indonesia Sustainability Reporting Award, Joseph et al. (2016) prove that disclosing anti-corruption practices in both countries is still low. Unlike Joseph et al. (2016), whose research attempts to determine the extent of anti-corruption information disclosure, this study aims to prove the impact of ownership structure, board of commissioners, and diversification on anti-corruption disclosures the Indonesian Stock Exchange listed-companies during 2013-2017. The Period of 2013-2017 was used to highlight the impact of the Indonesian Financial Services Authority recommendation on anti-corruption and anti-fraud policies disclosure in Indonesian listed company annual report.

Some previous researches examine various factors, for instances, good corporate governance and fundamental conditions of company, which encourage companies to engage in the disclosures of anti-corruption policies (Healy \& Serafeim, 2016; Tirtasari \& Hartomo, 2019; Hartomo \& Silvia, 2019 and Sari et al., 2020). However, this study examines the impact of ownership structure, board of directors, and company diversification on anti-corruption disclosure in Indonesia. The ownership structure covers managerial ownership, government ownership, and block holder ownership, while the board of directors refers to the board's independence and number.

Managerial ownership plays a role in harmonizing the management's interests and other stockholders (Jensen \& Meckling, 1976). Sepasi, Kazempour, \& Mansourlakoraj (2016) investigate the relationship between ownership structure and disclosure quality and prove that managerial ownership harms disclosure quality. Enough control mechanisms and supervision should be established to reduce the contrast between the managers and the firm's owners. One of these mechanisms is firm domination. If the mechanisms of firm domination work well, they will reduce opportunistic and jobbery behavior of the manager, which can increase the quality of disclosure.

High levels of block holding ownership mean that a few numbers of people only control stocks, and as a result, concentrated ownership occurs. A high level of block holder ownership has more power to demand managers to be more transparent because block holders want to know whether their funds are appropriately managed (Edmans, 2014). The structure of block holder ownership will strengthen company supervision and transparency, reflecting the higher level of anti-corruption disclosure policy.

Government stock ownership causes a company to operate in harmony to meet the interests of the government. The company will comply with procedures and rules concerned with corruption preventions. Consequently, this type of ownership allows disclosures that are completeness. Sepasi et al. (2016) claim a positive correlation between government ownership structure and anti-corruption disclosures. (Sari et al., 
2020) state that government ownership is not a significant predictor of anti-corruption disclosures. Thus, the governments do not have sufficient time and 'energy' to coercively push companies to disclose anti-corruption activities (Sari et al., 2020). This research aims to reexamine this condition in the Indonesian context.

A more diversified company, the more complicated business operation and will face more severe challenges in fighting corruption. An opportunistic manager who mainly works to serve his interests is most likely to conceal unlawful actions, including corruption, in his company. In this type of company, it is challenging to detect corruption practices due to its more complex business activities (Healy \& Serafeim, 2016). A manager in such a company has more room to be dishonest and tries his best to cover his company's wrongdoings from external parties. Diversified companies are then expected to be more engaged and transparent in revealing anti-corruption policies.

Independent commissioners' presence will reduce vested interests and pressures on the company, and this condition enables a director to make accountable and transparent decisions. Independent commissioners play a role in increasing transparency on corporate information reporting. This condition allows the company to share more information to investors, including the information on anti-corruption disclosures. Tirtasari \& Hartomo (2019) and Healy \& Serafeim (2016) prove a positive impact of board of commissioners independence on anti-corruption disclosures.

The number of board of commissioners determines the quality of supervision in a company. More commissioners mean proper supervision can be carried out. Proper supervisions enable a company to be more transparent in delivering corporate information (Kamwana \& Ombati, 2018), and one possible information to share is the anti-corruption policies. In her research (Maharesti, 2018), the board of commissioner independence positively impacts the company's social disclosures. The disclosure of anti-corruption practices is an example of a company's social disclosures.

This study examines the impact of factors determining anti-corruption disclosure in an Indonesian listed company. We examine the ownership structure factors, board of directors factors, and diversification on anti-corruption disclosure. Ownership structure factors refer to managerial ownership, block holder ownership, and government ownership. Meanwhile, the board of director factors refers to board independence and the board of commissioners' size.

\section{METHOD}

The populations of this research are the IDX listed companies during 2013-2017. The samples are the IDX listed companies issuing annual reports, especially the ones meeting the following criteria: their annual reports there are accessible, their financial statements are reported in the Indonesian Rupiah, and they provide complete data to become research samples. The sampling technique uses purposive sampling, which determines samples based on specific criteria - the final sample results obtained by 1864 companies with an explanation, as shown in Table 1.

The dependent variable of this research is the disclosure of anti-corruption policies. The variable is measured using the (Dissanayake, Islam, \& Dellaportas, 2012)'s anti-corruption index. The Dissanayake et al. (2012) measure was employed because it was comprehensively developed through a detailed analysis of several International Governmental Organizations guidelines for anti-bribery movement: United Nations, World Bank, Transparency International, and World Economic Forum (Joseph et al., 2016).

This work is licensed under a Creative Commons Attribution-ShareAlike 4.0 International License. 
Table 1. Sample Selection

\begin{tabular}{llrrrrrr}
\hline No & \multicolumn{1}{c}{ Explanation } & 2013 & 2014 & 2015 & 2016 & 2017 & Total \\
\hline 1. & IDX Listed Companies in 2013-2017 & 433 & 456 & 465 & 465 & 491 & 2355 \\
2. & Inaccessible information & $(31)$ & $(30)$ & $(32)$ & $(18)$ & $(19)$ & $(130)$ \\
3. & Financial statements in the & $(67)$ & $(62)$ & $(71)$ & $(69)$ & $(67)$ & $(336)$ \\
& Indonesian Rupiah & & & & & & \\
4. & Incomplete research data & $(7)$ & $(7)$ & $(5)$ & $(3)$ & $(3)$ & $(25)$ \\
& & & & & & \\
& Total Sample & 328 & 357 & 357 & 401 & 421 & 1864 \\
\hline
\end{tabular}

This research's independent variables are managerial ownership, block holder ownership, government ownership, the diversification of subsidiaries, the board of commissioners' independence and size, and the board size.

The managerial ownership is the stock proportion commonly owned by the board of directors and commissioners. The structure of block holder ownership is the stockholders' stock proportion, and it comprises 5\% or more of ownership. The government ownership structure is measured with a dummy variable: the value is 0 if the government owns stock proportion, while the value is one if the government does not. The diversification variable is also measured with a dummy variable. The value is 0 if the holding and subsidiary companies operate in the same business segment, while the value is one if both operate in different segments. The board of commissioners' independence refers to the number of independent board of commissioners after they are divided by the total number of commissioners. At the same time, the board of commissioners' number of the board commissioners in a company. This study uses Multiple Linear Regression to analyze the available research data.

\section{RESULT AND DISCUSSION}

As many as 1864 preliminary data are used in this study. By using the Normality Test, the number of preliminary data is then narrowed down to 904 final samples (Table 2).

Table 2. The Results of Descriptive Statistics

\begin{tabular}{lrrrrr}
\hline & N & Minimum & Maximum & Mean & $\begin{array}{c}\text { Std. } \\
\text { Deviation }\end{array}$ \\
\hline Managerial Ownership & 904 & 0,00 & 89,44 & 5,7873 & 14,77061 \\
Blockholder Ownership & 904 & 7,18 & 100,00 & 70,9947 & 17,24522 \\
Board of Commissioner Size & 904 & 2,00 & 10,00 & 3,5962 & 1,44275 \\
Board of Commissioner & 904 & 0,13 & 0,83 & 0,3986 & 0,10893 \\
Independence & & & & & \\
Anti-corruption Disclosures & 904 & 0,00 & 0,35 & 0,0514 & 0,04976 \\
\hline Valid N (listwise) & 904 & & & & \\
\hline
\end{tabular}

The Descriptive Statistics analysis shows that the level of anti-corruption policy disclosures in Indonesian companies is still deficient with an average score of 0,0514. The score shows an irony since the Indonesian Financial Service Authority (Otoritas Jasa Keuangan) has issued a Letter No. 32 / SEOJK.04 / 2015, stating that Indonesian companies are recommended to have anti-corruption and anti-fraud policies. Unfortunately, these recommendations are beyond implementation because it is considered to be voluntary and unbinding in nature. 
Managerial ownership indicates a minimum value of 0.000 (ADES in year 2013) and a maximum value of 89.44 (BTON in year 2017). The average value or mean value of the managerial ownership is 5.7873, and the deviation standard is 14.77061. The data show that the manager's percentage of shares is not strong enough to influence company decisions.

The minimum value of block holder ownership is 7.18 (PLAS in the year 2017), and the maximum value is 100.00 (BRIS in the year 2017), while the average value is 70.9947. However, there is a high average of block holder ownership, but still no rules governing block holders' ownership in an Indonesian company.

The minimum value of the board of commissioners' size variable is 2.00 (APIC in year 2013), and the maximum value is 10.00 (AUTO in year 2013) with an average value of 3.5962 and the deviation standard, 1.44275. The average value implies that all samples have complied with the regulation of the Indonesian Financial Service Authority No. 33/POJK.04/2014 requiring every company to have at least two members of the commissioner board.

The independent commissioner variable indicates a minimum value of 0,125 (KMTR in year 2017) and a maximum value of 0.75 (BRIS in year2017) with an average value of 0.3985 and the deviation standard, 0.10860 . It can be concluded that, on average, the number of independent commissioners of the sample companies is already following the Regulation of the Indonesian Financial Service Authority No. 33 /POJK.04/2014, concerning the number of independent commissioners, should meet the minimum $30 \%$ of the total number of commissioners.

Table 3. The Results of Frequency Statistics

\begin{tabular}{lcccc}
\hline & Frequency & Percent & Valid Percent & Cumulative percent \\
\hline Government Ownership & & & & \\
Valid 0 & 687 & 75,7 & 75,7 & 75,7 \\
Valid 1 & 217 & 24,3 & 24,3 & 100,0 \\
\hline Total & 904 & 100,0 & 100,0 & \\
\hline Diversification & & & & \\
Valid 0 & 678 & 74,2 & 74,2 & 74,2 \\
Valid 1 & 226 & 25,8 & 25,8 & 100,0 \\
\hline Total & 904 & 100,0 & 100,0 & \\
\hline
\end{tabular}

The frequency statistics (Table 3) show that the government ownership variable has 24,3 percent of the Indonesian government's total sample, and the Indonesian government does not own 75,7 percent. This data shows that majority of the sample is not a government-owned company. Regarding the diversification variable, frequency statistics show that 25,8 percent of parent companies have different subsidiary company segments and 74,2 percent of parent companies have the same subsidiary. This show that the majority of the sample are non-diversified company.

The Impact of Managerial Ownership on Company's Anti-corruption Disclosures

The results in Table 4 indicate that managerial ownership positively impacts the anti-corruption disclosures in a company. Manager's stock ownership can reduce agency costs. That condition is possible because this kind of ownership plays a role in harmonizing the management's interests and other types of stockholders (Jensen \& 
Meckling, 1976). (Sepasi et al., 2016) provides empirical proof that the management's stock ownership level positively impacts the amount of information shared by a company in its annual report. The reason is that individuals act in harmony to achieve their personal goals, which helps their organization reach its own goals, as the Goal Congruence theory (Warfield, Wild, \& Wild, 1995) also suggests. In line with this theory, the presence of common goals, for instance, to achieve the best results, between the managers and stockholders, will lead to the increase of transparencies, including disclosing anti-corruption policies (Tirtasari \& Hartomo, 2019).

This study proves a positive impact of managerial ownership on the scope of anti-corruption policy disclosures in a company. This study strengthens the Agency Theory (Jensen \& Meckling, 1976), predicting a positive correlation between the managerial interests and the disclosures of financial statement information. Managerial interests also have a positive impact on the scope of anti-corruption disclosures in financial statements. That condition is possible because managerial ownership plays a significant role in harmonizing the management's interests and the stockholders' interests, but the managers.

Table 4. Test Result

\begin{tabular}{llrr}
\hline \multicolumn{1}{c}{ Model } & Standardized Coefficients Beta & \multicolumn{1}{c}{ Sig. } \\
\hline 1 (Constant) & & $-4,384$ &, 000 \\
Managerial Ownership &, 058 & 3,764 &, 000 \\
Blockholder Ownership &,- 121 & $-7,828$ &, 000 \\
Government Ownership &, 600 & 37,056 &, 000 \\
Diversification &, 094 & 6,142 &, 000 \\
BC Size &, 431 & 26,056 &, 000 \\
BC Independence &, 204 & 13,141 &, 000 \\
\hline
\end{tabular}

\section{The Impact of Blockholder Ownership on Company's Anti-corruption Disclosures}

Structures of block holder ownership negatively impact on company's anticorruption disclosures. Blockholder ownership refers to investors' stocks commonly owned whose own position is significant for their common stocks. The high level of block holder ownership allows the block holders to demand their managers for transparencies. The demand makes sense because the block holders want to know whether their financial investment is appropriately managed (Sepasi et al., 2016). The argument is that because the block holder ownership structure tends to be centralized, other parties will find it difficult to challenge the block holers' interests or wishes. This situation gives higher chances of fraud.

Centralized block holder ownership helps facilitate stockholders deciding on disclosing the company's anti-corruption policies (Sepasi et al., 2016). The lower the level of block holder ownership, the better chance for a company to engage in anticorruption policy disclosures. The vital role of block holders motivates them to pay for monitoring or monitoring the company's management performance (Edmans, 2014). When shareholders do not have a majority interest, it is less economical for individual shareholders to incur high monitoring costs because they will only receive a small benefit. This research finding, consistent with Al-bassam et al. (2018), shows an increase in block ownership significantly reduces disclosure. Al-bassam et al. (2018) state that block holder ownership can serve as a substitute for adequate governance arrangements, including less disclosure relating to Corporate Governance practices. 


\section{The Impact of Government Ownership on Company's Anti-Corruption Disclosures}

The structure of government ownership has a positive impact on the company's anti-corruption disclosures. The government's stock ownership makes a company operate in harmony with the interests of the government. A government company will comply with procedures or regulations concerning with anti-corruption measures. In such a condition, the government can monitor the company much better. Although inconsistent with (Sari et al., 2020). The result of this study is in line with a research carried out by Sepasi et al. (2016), Eng \& Mak (2003), and Huafang \& Jianguo (2007), who point out that the structure of government ownership has a positive impact on the disclosures of company information, including the ones related to anti-corruption policies.

Indonesia government have commitments to combat corruption and articulate this commitment in their regulations. In this regulated condition, the governments potentially push companies to obey anti-corruption regulations and disclose their anticorruption actions. Government-owned companies themselves tend to be politically sensitive because their activities are more visible in front of the public eyes, and there is a higher expectation for them to be aware of their public duties (Muttakin \& Subramaniam, 2015).

\section{The Impact of Diversification on Company's Anti-corruption Disclosures}

Subsidiary diversification has a positive impact on the company's anti-corruption disclosures. One way to maintain and develop its business is by expanding business segments (Ataullah, Davidson, Le, \& Wood, 2014). A diversified company will face asymmetric information, and as a result, it will share more information to overcome the asymmetric information (Healy \& Serafeim, 2016). Another argument claims that subsidiary companies with different business segments will have more complicated business operations. This condition causes the subsidiary companies to be vulnerable to corruption.

A company needs to disclose more information to prevent corruption. The more diversified a company is, the more information it contributes to anti-corruption disclosures. More anti-corruption disclosures will boost management transparency and reduce asymmetric information. The disclosure of anti-corruption policies manifests the diversified companies' management transparency, the type of companies characterized by more complex operations than those only focusing on primary competence.

\section{The Impact of the Board Independence on Company's Anti-corruption Disclosures}

Board independence has a positive impact on the company's anti-corruption disclosures. The more a company has independent commissioners, the more opportunities the company has to engage in anti-corruption disclosures. An independent commissioners most likely to supply and disclose information to investors. The board of commissioners' independence is gained if the number of outside commissioners is higher than inside commissioners. When this happens, monitoring and supervising processes will be better executed because the company management's chances to commit dishonest behaviors are limited (Healy \& Serafeim, 2016).

The independent commissioners are more objective in perceiving corporate matters, and this condition encourages the company to disclose information, including providing relevant information for the company investors. This study supports the 
result of Tirtasari \& Hartomo (2019) and Healy \& Serafeim (2016), who also highlight that the board of commissioners' role is to supervise management's decisions. The increasing number of independent commissioners will yield quality supervision, as portrayed in the increase of anti-corruption disclosures.

\section{The Impact of the Board of Commissioner Size on Company's Anti-corruption Disclosures}

The size of the board of commissioners has a positive impact on the company's anti-corruption disclosures. The more significant number of commissioners a company has, the greater the commissioners' greater power to bring management pressure for company information disclosures and transparency (Kamwana \& Ombati, 2018). In other words, the board's bigger size will cause monitoring processes to be more effective, which conditions the company to share company information. For a company, anti-corruption policies should be a part of voluntary disclosures that reflect its transparency.

This study's result is in line with Maharesti (2018), stating that the board of commissioners' size has a positive impact on a company's social disclosures, including the disclosures of anti-corruption policies. The more significant number of commissioners' board will increase commitment to anti-corruption policies, guiding and enhancing company compliance to business ethics principles. The more significant number of commissioners' board also provides active support for the implementation and compliance of business ethics policy, including anti-corruption activity.

\section{CONCLUSION}

This research concludes that the disclosure level of the anti-corruption Indonesian listed companies' anti-corruption policies in 2013-2017 is relatively low. It implies that Indonesian companies have made a little effort to prevent and combat corruption. It is true that the Indonesian Financial Services Authority (Otoritas Jasa Keuangan, 2015) in its Indonesian Corporate Governance Roadmap 2015 and Circular Letter No. 32/SEOJK.04/ recommend that Indonesian companies to have anticorruption and anti-fraud policies. The reality is that this recommendation is not fully executed because many consider it as optional and non-binding.

The managerial ownership, government ownerships, diversifications, the independence, and size of the board of commissioners have positive impacts on disclosing the company's anti-corruption policies, while the block holder ownership negatively impacts the company's anti-corruption disclosures. Conclusion This condition indicates that all factors suspected of affecting the disclosure of anticorruption policies are proven to impact the disclosure of anti-corruption policies significantly.

This research's scope is only limited to the three factors impacting anti-corruption disclosures, namely, ownership structure, diversification, and board of commissioners. It means that this research has not covered the whole aspects of corporate governance and company characteristics. Besides, it has not examined each group or industrial sector listed on the Indonesian Stock Exchange (IDX) to find out the impact of industrial factors on the disclosure of anti-corruption policies. This research also excludes industrial sectors exposed to a high risk of corruption, such as mining, oil and gas, forestry, or construction. Future researchers can carry out a complete examination of the governance variables such as the governance committee's presence, the competence of the audit committee, and the company characteristic variables such as industrial risks, auditor quality, and company's financial conditions. 


\section{REFERENCES}

Al-bassam, W. M., Ntim, C. G., Opong, K. K., \& Downs, Y. (2018). Corporate Boards and Ownership Structure as Antecedents of Corporate Governance Disclosure in Saudi Arabian Publicly Listed Corporations. Business \& Society, 57(2), 335-377. https://doi.org/10.1177/0007650315610611

Ataullah, A., Davidson, I., Le, H., \& Wood, G. (2014). Corporate Diversification, Information Asymmetry, and Insider Trading. British Journal of Management, 25, 228-251. https://doi.org/10.1111/j.1467-8551.2012.00846.x

De Melo, R. B., \& Patten, D. (2015). Essays on anti-corruption disclosure. Doctoral Thesis in Business and Management Sciences (August). Retrieved from https://repositorio-aberto.up.pt/bitstream/10216/83121/2/122841.pdf

Dissanayake, T., Islam, M. A., \& Dellaportas, S. (2012). Corporate Disclosure on Combating Bribery: A Study of Two Global Companies in the Telecommunication Industry, 1-45. Retrieved from https://pdfs.semanticscholar.org/bad5/09d1e5e69a2b0b2e0f41257029f9e84689e4 .pdf?_ga=2.121697475.991476281.1585711991-1608473328.1572248178

Edmans, A. (2014). Blockholders and Corporate Governance. Annual Review of Financial Economics, (6), 23-50. https://doi.org/10.1146/annurev-financial110613-034455

Eng, L. L., \& Mak, Y. T. (2003). Corporate governance and voluntary disclosure. Journal of Accounting and Public Policy, 22, 325-345. https://doi.org/10.1016/S02784254(03)00037-1

Hartomo, O. D., \& Silvia, B. M. (2019). Anteseden Pengungkapan Kebijakan Anti Korupsi Perusahaan di Bursa Efek Indonesia. Jurnal Kajian Akuntansi, 3(2), 196209. Retrieved from https:/ / doi.org/10.1108/SAMPJ-10-2013-0042

Healy, P. M., \& Serafeim, G. (2016). An Analysis of Firms' Self-Reported Anticorruption Efforts. The Accounting Review, 91. No.2(March 2016), 489-511. https://doi.org/10.2308/accr-51191

Huafang, X., \& Jianguo, Y. (2007). Ownership structure, board composition, and corporate voluntary disclosure. Evidence from listed companies in China. Managerial Auditing Journal, 22(6), 604-619. https://doi.org/10.1108/02686900710759406

Jensen, M. C., \& Meckling, W. H. (1976). Theory of the firm: managerial behavior, agency costs, and ownership structure. Journal of Financial Economics, 3, 305360. Retrieved from https://www.sciencedirect.com/science/article/pii/0304405X7690026X

Joseph, C., Gunawan, J., Sawani, Y., Rahmat, M., Noyem, J. A., \& Darus, F. (2016). A comparative study of anti-corruption practice disclosure among Malaysian and Indonesian Corporate Social Responsibility (CSR) best-practice companies. Journal of Cleaner Production, 112, 2896-2906. https://doi.org/10.1016/j.jclepro.2015.10.091

Kamwana, M. K., \& Ombati, R. (2018). Effect of Selected Board Characteristics on Financial Voluntary Disclosure among Manufacturing Firms Listed in Nairobi Securities Exchange. International Journal of Business and Social Science, 9(12), 141-148. https://doi.org/10.30845/ijbss.v9n12p15

Maharesti, W. S. (2018). Pengaruh ukuran dewan komisaris, ukuran perusahaan, profitabilitas, kinerja lingkungan dan liputan media terhadap pengungkapan corporate social responsibility. Universitas Islam Indonesia Repository. Retrieved from https:/ / dspace.uii.ac.id/handle/123456789/7557 
Muttakin, M. B., \& Subramaniam, N. (2015). Firm ownership and board characteristics: do they matter for corporate social responsibility disclosure of Indian companies? Sustainability Accounting, Management and Policy Journal, 6(2), 145. Retrieved from https:/ / doi.org/10.1108/SAMPJ-10-2013-0042

Otoritas Jasa Keuangan. (2015). Roadmap Tata Kelola Perusahaan Indonesia. Retrieved from https://www.ojk.go.id/id/data-dan-statistik/ojk/Documents/ ROADMAPTATAKELOLA PERUSAHAANINDONESIA_ 1391520776.PDF

Sari, T. K., Cahaya, F. R., \& Joseph, C. (2020). Coercive Pressures and Anti-corruption Reporting: The Case of ASEAN Countries. Journal of Business Ethics, (0123456789). https://doi.org/10.1007/s10551-020-04452-1

Sepasi, S., Kazempour, M., \& Mansourlakoraj, R. (2016). Ownership Structure and Disclosure Quality: Case of Iran. Procedia Economics and Finance, 36(16), 108112. https://doi.org/10.1016/S2212-5671(16)30021-1

Tirtasari, I. D. A., \& Hartomo, O. D. (2019). Pengaruh GCG Dan Karakteristik Perusahaan Terhadap Kecenderungan Mengungkapkan Kebijakan Anti Korupsi. Jurnal Akuntansi Bisnis, 17(2), 131-149. Retrieved from http://journal.unika.ac.id/index.php/jab/article/view/2337/pdf

Transparency International. (2019). Corruption perceptions index 2019. Retrieved from https://www.transparency.org/cpi2019

Warfield, T. D., Wild, J. J., \& Wild, K. L. (1995). Managerial ownership, accounting choices, and informativeness of earnings. Journal of Accounting and Economics, 20, 61-91. Retrieved from https://www.sciencedirect.com/science/article/abs/pii/ 016541019400393J 